\title{
KRIMINALISASI DALAM UU NO. 24 TAHUN 2007 TENTANG \\ PENANGGULANGAN BENCANA
}

Oleh :

I Gede Widhiana Suarda, S.H., M.Hum ${ }^{\infty}$

\begin{abstract}
ABSTRAK
Undang-Undang Nomor 24 Tahun 2007 tentang Penanggulangan Bencana merupakan salah satu sumber hukum pidana positif, oleh karena UU tersebut merumuskan Bab Ketentuan Pidana mulai Pasal 75 sampai dengan Pasal 79. Berdasarkan ketentuan pidana tersebut akan dapat diindetifikasi perbuatan-perbuatan apa saja yang merupakan tindak pidana penanggulangan bencana. Lebih lanjut, apabila ada yang melakukan perbuatan yang dilarang itu maka aparat peradilan pidana (polisi, jaksa, hakim, dan pemasyarakatan) akan melakukan penindakan dan penjatuhan pidana. Dengan demikian, UU No. 24 Tahun 2007 telah melakukan kriminalisai terhadap beberapa perbuatan yang terkait dengan masalah kebencanaan. Namun, sekalipun telah diundangkan bukan berarti persoalan telah selesai. Kebijakan kriminalisasi dalam UU No. 24 tahun 2007 tetap harus dianalisis guna mengantisipasi perbuatan-perbuatan kriminal sehubungan dengan penanggulangan bencana di Indonesia. Kajian yang dapat digunakan dalam rangka menganalisis kebijakan kriminalisasi dalam UU No. 24 tahun 2007 adalah kajian politik hukum pidana.
\end{abstract}

Kata kunci: Ketentuan Pidana, Kriminalisasi, Tindak Pidana Penanggulangan Bencana, Politik Hukum Pidana.

\section{PENDAHULUAN}

Data internasional menunjukkan bahwa lebih dari 2,2 juta penduduk dunia meninggal sia-sia akibat bencana alam dalam tiga dasawarsa terakhir. Dalam periode yang sama, nilai kerugian ekonomi akibat semua peristiwa itu mencapai 1.500 triliun dollar AS. Dampak terburuk, baik dari jumlah korban yang tewas dan cedera maupun kerugian ekonomi, paling banyak dialami negara-negara berkembang. Data tersebut tertuang dalam 2009 Global Assesment Report on Disaster Risk Reduction yang diluncurkan PBB di Sanur - Bali pada tanggal 18 Mei lalu (Kompas, 19 Mei 2009, hal. 10). Kerugian-kerugian yang diakibatkan oleh bencana alam juga sangat mungkin

\footnotetext{
${ }^{\infty}$ Dosen Fakultas Hukum Universitas Jember.
} 
terjadi di Indonesia. Oleh karena, Indonesia adalah salah satu negara yang sangat rawan terkena bencana berdasarkan kondisi geografis, geologis, hidrologis, dan demografis.

Bencana yang terjadi dapat disebabkan oleh faktor alam dan non alam. Yang termasuk faktor alam seperti gempa bumi, tsunami, gunung meletus, tanah longsor, banjir, angin topan, sementara yang termasuk faktor non alam seperti gagal teknologi, epidemi, wabah penyakit, maupun faktor manusia yang menyebabkan timbulnya korban jiwa manusia, kerusakan lingkungan, kerugian harta benda dan dampak psikologis yang dalam keadaan tertentu dapat menghambat pembangunan nasional (Bapenas dan UNDP, 2008:1). Dalam rangka mengantisipasi dan mengurangi berbagai akibat dari bencana tersebut maka diperlukan adanya suatu kebijakan legislasi dari pemerintah sebagai payung hukum yang mengatur tentang kebencanaan. Jadi, dengan kondisi Indonesia yang rawan bencana harus diikuti juga dengan kebijakan legislasi di bidang kebencanaan. Dan, hal ini telah dilakukan oleh pemerintah, yaitu dengan ditetapkannya UU No. 24 tahun 2007 tentang Penanggulangan Bencana.

Dalam penjelasan umum UU No. 24 tahun 2007 tentang Penanggulangan Bencana (selanjutnya disebut UUPB) dinyatakan bahwa penanggulangan bencana merupakan salah satu bagian dari pembangunan nasional yaitu serangkaian kegiatan Penanggulangan Bencana sebelum, pada saat maupun sesudah terjadinya bencana. Selama ini masih dirasakan adanya kelemahan baik dalam pelaksanaan Penaggulangan Bencana maupun yang terkait dengan landasan hukumnya. Karena belum ada Undangundang yang secara khusus menangani bencana. Mencermati hal-hal tersebut diatas dan dalam rangka memberikan landasan hukum yang kuat bagi penyelenggaraan Penanggulangan Bencana, disusunlah Undang-Undang tentang Penanggulangan Bencana yang pada prinsipnya mengatur tahapan bencana meliputi pra bencana, saat tanggap darurat dan pasca bencana. Materi muatan UUPB memuat ketentuan-ketentuan pokok sebagai berikut (Penjelasan Umum UUPB):

1. Penyelenggaraan penanggulangan bencana merupakan tanggung jawab dan wewenang Pemerintah dan pemerintah daerah, yang dilaksanakan secara terencana, terpadu, terkoordinasi, dan menyeluruh.

2. Penyelenggaraan penanggulangan bencana dalam tahap tanggap darurat dilaksanakan sepenuhnya oleh badan nasional penanggulangan bencana dan badan penanggulangan bencana daerah. Badan penanggulangan bencana tersebut terdiri dari unsur pengarah dan unsur pelaksana. Badan nasional penanggulangan bencana 
dan badan penanggulangan bencana daerah mempunyai tugas dan fungsi antara lain pengkoordinasian penyelenggaraan penanggulangan bencana secara terencana dan terpadu sesuai dengan kewenangannya.

3. Penyelenggaraan penanggulangan bencana dilaksanakan dengan memperhatikan hak masyarakat yang antara lain mendapatkan bantuan pemenuhan kebutuhan dasar, mendapatkan pelindungan sosial, mendapatkan pendidikan dan keterampilan dalam penyelenggaraan penanggulangan bencana, berpartisipasi dalam pengambilan keputusan.

4. Kegiatan penanggulangan bencana dilaksanakan dengan memberikan kesempatan secara luas kepada lembaga usaha dan lembaga internasional.

5. Penyelenggaraan penanggulangan bencana dilakukan pada tahap pra bencana, saat tanggap darurat, dan pasca bencana, karena masingmasing tahapan mempunyai karakteristik penanganan yang berbeda.

6. Pada saat tanggap darurat, kegiatan penanggulangan bencana selain didukung dana APBN dan APBD juga disediakan dana siap pakai dengan pertanggungjawaban melalui mekanisme khusus.

7. Pengawasan terhadap seluruh kegiatan penanggulangan bencana dilakukan oleh Pemerintah, pemerintah daerah, dan masyarakat pada setiap tahapan bencana, agar tidak terjadi penyimpangan dalam penggunaan dana penanggulangan bencana.

8. Untuk menjamin ditaatinya undang-undang ini dan sekaligus memberikan efek jera terhadap para pihak, baik karena kelalaian maupun karena kesengajaan sehingga menyebabkan terjadinya bencana yang menimbulkan kerugian, baik terhadap harta benda maupun matinya orang, menghambat kemudahan akses dalam kegiatan penanggulangan bencana, dan penyalahgunaan pengelolaan sumber daya bantuan bencana dikenakan sanksi pidana, baik pidana penjara maupun pidana denda, dengan menerapkan pidana minimum dan maksimum.

Berdasarkan hal-hal yang diatur dalam undang-undang tersebut, kajian dalam tulisan ini akan difokuskan pada pengaturan Ketentuan Pidana-nya. Dari kajian ilmu hukum pidana, dengan diaturnya Bab Ketentuan Pidana dalam UUPB berarti telah terjadi proses 'kriminalisasi' terkait dengan masalah kebencanaan. Maksud dari kriminalisasi adalah suatu proses untuk menjadikan suatu perbuatan yang dulunya bukan merupakan tindak pidana kemudian menjadi tindak pidana. Proses ini tampak 
nyata setelah disahkannya suatu peraturan perundang-undangan yang didalamnya menggunakan sanksi pidana.

Sejalan dengan itu, permasalahan yang patut dimunculkan adalah perbuatanperbuatan apa saja yang ditetapkan sebagai tindak pidana menurut UUPB? Permasalahan lainnya adalah apakah undang-undang tersebut mengatur juga tentang kerusakan lingkungan sebagaimana yang diatur dalam UU No. 23 tahun 1997 tentang Lingkungan Hidup? Bagaimana penyelesaian hukumnya? Bagaimana perlindungan hukum bagi para korban? Bagaimana pengaturan sanksi pidana terhadap korporasinya? Dan masih banyak lagi permasalahan lainnya yang terkait dengan korban bencana dan lembaga-lembaga terkait (pemerintah pusat, pemerintah daerah, LSM dan sebagainya).

Dari berbagai persoalan tersebut, fokus permasalahan yang akan dikaji dalam tulisan ini adalah: (1) perbuatan apa saja yang ditetapkan sebagai tindak pidana menurut UUPB? (2) kebijakan apakah yang seyogyanya dilakukan guna pembaharuan Bab Ketentuan Pidana dalam UUPB? Sehubungan dengan permasalahan tersebut, tujuan dari tulisan ini adalah: (1) memberikan sosialisasi kepada masyarakat tentang tindak pidana penanggulangan bencana, dan (2) melakukan analisis tentang kelemahankelemahan kebijakan formulasi atau kebijakan kriminalisasi dalam rangka pembaharuan UUPB dimasa mendatang.

\section{PEMBAHASAN}

\subsection{TINDAK PIDANA BERDASARKAN UU NO. 24 TAHUN 2007}

Pengesahan UUPB pada tahun 2007 tentu harus diapresiasi positif, yaitu sebagai salah satu wujud kepedulian pemerintah terhadap masyarakat Indonesia yang berada dalam kondisi rawan bencana. UUPB telah menggariskan beberapa hal yang berhubungan dengan masalah kebencanaan, termasuk juga mengenai pembentukan badan atau lembaga yang khusus menangani masalah kebencanaan, yaitu Badan Nasional Penanggulangan Bencana (BNPB). Lembaga ini telah terbentuk dengan seorang kepala yang telah diangkat oleh presiden, yaitu Syamsul Maarif. Badan Nasional Penanggulangan Bencana (selanjutnya disingkat BNPB) adalah lembaga pemerintah nondepartemen setingkat menteri dengan fungsi sebagai berikut (Pasal 13 UUPB): 
a. merumuskan dan menetapkan kebijakan penanggulangan bencana dan penanganan pengungsi dengan bertindak cepat dan tepat serta efektif dan efisien; dan

b. mengkoordinasikan pelaksanaan kegiatan penanggulangan bencana secara terencana, terpadu, dan menyeluruh.

Sebagaimana telah disinggung dalam Pendahuluan bahwa dengan diaturnya BAB tentang Ketentuan Pidana dalam UUPB maka telah terjadi kriminalisasi sehubungan dengan penanggulangan bencana. Soedarto (1986:31-32) menyatakan bahwa kriminalisasi sebagai proses penetapan suatu perbuatan orang sebagai perbuatan yang dapat dipidana. Proses ini diakhiri dengan terbentuknya undang-undang dimana perbuatan itu diancam dengan suatu sanksi yang berupa pidana. Lebih lanjut dinyatakan, bahwa dengan itu telah terbentuk peraturan hukum pidana yang siap untuk diterapkan oleh hakim dan selanjutnya apabila dijatuhkan pidana, dilaksanakan oleh kekuasaan administrasi (eksekusi. Pen). Dari hal tersebut dapat disimpulkan bahwa UUPB juga merupakan bagian dari hukum pidana positif. Setiap undang-undang yang menggunakan sanksi pidana didalamnya merupakan bagian dari hukum pidana positif.

Pertanyaanya sekarang adalah, perbuatan-perbuatan apa saja yang dijadikan tindak pidana dalam UUPB. Untuk mengetahui perbuatan-perbuatan apa saja yang dijadikan tindak pidana dalam UUPB maka harus dilihat dalam BAB tentang Ketentuan Pidana. Dalam UUPB, Ketentuan Pidana diatur dalam BAB X dari Pasal 75 sampai dengan Pasal 79. Lebih lanjut, analisis tentang perbuatan apa saja yang dikriminalisasikan akan berpijak pada ketentuan Pasal 75 sampai dengan Pasal 79

UUPB. Analisis akan dilakukan berdasarkan metode penafsiran gramatikal. Hasil lengkapnya dapat dilihat dalam tabel berikut:

Tabel 1. Analisis Tentang Tindak Pidana Penanggulangan Bencana Dalam UUPK

\begin{tabular}{|l|l|l|}
\hline \multicolumn{2}{|c|}{ Pasal dan Ayat } & \multicolumn{1}{c|}{ Tindak Pidana } \\
\hline 75 & (1) Setiap orang yang karena kelalaiannya & 1. Terjadinya bencana \\
& karena melakukan \\
& melakukan pembangunan berisiko tinggi, & kegiatan pembangunan \\
& yang tidak dilengkapi dengan analisis risiko & berisiko tinggi. Kegiatan \\
& bencana sebagaimana dimaksud dalam Pasal & pembagunan tersebut \\
& $\begin{array}{l}\text { 40 ayat (3) yang mengakibatkan terjadinya } \\
\text { bencana, dipidana dengan pidana penjara }\end{array}$ & tidak disertai dengan \\
& paling singkat 3 (tiga) tahun atau paling lama & analisis risiko bencana. \\
\hline
\end{tabular}




\begin{tabular}{|c|c|c|}
\hline & $\begin{array}{l}\text { 6 (enam) tahun dan denda paling sedikit Rp. } \\
300.000 .000,00 \text { (tiga ratus juta rupiah) atau } \\
\text { denda paling banyak Rp. 2.000.000.000,00 } \\
\text { (dua miliar rupiah). } \\
\text { (2) Dalam hal tindak pidana sebagaimana } \\
\text { dimaksud pada ayat (1) mengakibatkan } \\
\text { timbulnya kerugian harta benda atau barang, } \\
\text { pelaku dipidana dengan pidana penjara paling } \\
\text { singkat } 6 \text { (enam) tahun atau paling lama } 8 \\
\text { (delapan) tahun dan denda paling sedikit Rp. } \\
600.000 .000,00 \text { (enam ratus juta rupiah) atau } \\
\text { denda paling banyak Rp. 3.000.000.000,00 } \\
\text { (tiga miliar rupiah). } \\
\text { (3) Dalam hal tindak pidana sebagaimana } \\
\text { dimaksud pada ayat (1) mengakibatkan } \\
\text { matinya orang, pelaku dipidana dengan } \\
\text { pidana penjara paling singkat } 8 \text { (delapan) tahun } \\
\text { atau paling lama } 10 \text { (sepuluh) tahun dan denda } \\
\text { paling sedikit Rp. 3.000.000.000,00 (tiga } \\
\text { miliar rupiah) atau denda paling banyak Rp. } \\
\text { 6.000.000.000,00 (enam miliar rupiah). }\end{array}$ & $\begin{array}{l}\text { 2. Adanya pemberatan } \\
\text { pidana apabila bencana } \\
\text { tersebut menimbulkan } \\
\text { kerugian harta benda atau } \\
\text { barang. } \\
\text { 3. Adanya pemberatan } \\
\text { pidana apabila bencana } \\
\text { tersebut menimbulkan } \\
\text { kematian seseorang. }\end{array}$ \\
\hline 76 & $\begin{array}{l}\text { (1) Dalam hal tindak pidana sebagaimana } \\
\text { dimaksud dalam Pasal } 75 \text { ayat (1) dilakukan } \\
\text { karena kesengajaan, pelaku dipidana dengan } \\
\text { pidana penjara paling singkat } 5 \text { (lima) tahun } \\
\text { atau paling lama } 8 \text { (delapan) tahun dan denda } \\
\text { paling sedikit Rp. 2.000.000.000,00 (dua } \\
\text { miliar rupiah) atau denda paling banyak Rp. } \\
4.000 .000 .000,00 \text { (empat miliar rupiah). } \\
\text { (2) Dalam hal tindak pidana sebagaimana } \\
\text { dimaksud dalam Pasal } 75 \text { ayat (2) dilakukan } \\
\text { karena kesengajaan, pelaku dipidana dengan } \\
\text { pidana penjara paling singkat } 8 \text { (delapan) tahun } \\
\text { atau paling lama } 12 \text { (dua belas) tahun dan } \\
\text { denda paling sedikit } \\
\text { 3.000.000.000,00 (tiga miliar rupiah) atau } \\
\text { denda paling banyak Rp. } 6.000 .000 .000,00 \\
\text { (enam miliar rupiah). } \\
\text { (3) Dalam hal tindak pidana sebagaimana } \\
\text { dimaksud dalam Pasal } 75 \text { ayat (3) dilakukan } \\
\text { karena kesengajaan, pelaku dipidana dengan } \\
\text { pidana penjara paling singkat } 12 \text { (dua belas) } \\
\text { tahun atau paling lama } 15 \text { (lima belas) tahun } \\
\text { dan denda paling sedikit Rp6.000.000.000,00 } \\
\text { (enam miliar rupiah) atau denda paling } \\
\text { banyak Rp12.000.000.000,00 (dua belas } \\
\text { miliar rupiah). }\end{array}$ & $\begin{array}{l}\text { 1. Adanya pemberatan } \\
\text { pidana apabila perbuatan } \\
\text { dalam Pasal } 75(1) \\
\text { dilakukan dengan } \\
\text { kesengajaan. } \\
\text { 2. Adanya pemberatan } \\
\text { pidana apabila perbuatan } \\
\text { dalam Pasal } 75(2) \\
\text { dilakukan dengan } \\
\text { kesengajaan. } \\
\text { 3. Adanya pemberatan } \\
\text { pidana apabila perbuatan } \\
\text { dalam Pasal } 75(3) \\
\text { dilakukan dengan } \\
\text { kesengajaan. }\end{array}$ \\
\hline 77 & $\begin{array}{l}\text { Setiap orang yang dengan sengaja menghambat } \\
\text { kemudahan akses sebagaimana dimaksud dalam } \\
\text { Pasal } 50 \text { ayat (1) dipidana dengan pidana penjara }\end{array}$ & $\begin{array}{l}\text { Menghambat kemudahan } \\
\text { akses BNPB dab BNPD. }\end{array}$ \\
\hline
\end{tabular}




\begin{tabular}{|c|c|c|}
\hline & $\begin{array}{l}\text { paling singkat } 3 \text { (tiga) tahun atau paling lama } 6 \\
\text { (enam) tahun dan denda paling sedikit Rp. } \\
2.000 .000 .000,00 \text { (dua miliar rupiah) atau denda } \\
\text { paling banyak Rp. } 4.000 .000 .000,00 \text { (empat } \\
\text { miliar rupiah). }\end{array}$ & \\
\hline 78 & $\begin{array}{l}\text { Setiap orang yang dengan sengaja } \\
\text { menyalahgunakan pengelolaan sumber daya } \\
\text { bantuan bencana sebagaimana dimaksud dalam } \\
\text { Pasal 65, dipidana dengan pidana penjara dengan } \\
\text { penjara seumur hidup atau pidana penjara paling } \\
\text { singkat } 4 \text { (empat) tahun atau paling lama } 20 \text { (dua } \\
\text { puluh) tahun dan denda paling sedikit Rp. } \\
6.000 .000 .000,00 \text { (enam miliar rupiah) atau denda } \\
\text { paling banyak Rp. } 12.000 .000 .000,00 \text { (dua belas } \\
\text { miliar rupiah). }\end{array}$ & $\begin{array}{l}\text { Penyalahgunaan sumber } \\
\text { daya bantuan bencana }\end{array}$ \\
\hline 79 & $\begin{array}{l}\text { (1) Dalam hal tindak pidana sebagaimana } \\
\text { dimaksud dalam Pasal } 75 \text { sampai dengan } \\
\text { Pasal } 78 \text { dilakukan oleh korporasi, selain } \\
\text { pidana penjara dan denda terhadap } \\
\text { pengurusnya, pidana yang dapat dijatuhkan } \\
\text { terhadap korporasi berupa pidana denda } \\
\text { dengan pemberatan } 3 \text { (tiga) kali dari pidana } \\
\text { denda sebagaimana dimaksud dalam Pasal } 75 \\
\text { sampai dengan Pasal } 78 \text {. } \\
\text { (2) Selain pidana denda sebagaimana dimaksud } \\
\text { pada ayat (1), korporasi dapat dijatuhi pidana } \\
\text { tambahan berupa: } \\
\text { a. pencabutan izin usaha; atau } \\
\text { b. pencabutan status badan hukum. }\end{array}$ & $\begin{array}{l}\text { a. Ketentuan pemidanaan } \\
\text { untuk pelaku korporasi } \\
\text { dengan ancaman berupa } \\
\text { pidana pokok dan pidana } \\
\text { tambahan. } \\
\text { b. Pidana pokoknya adalah } \\
\text { "denda" dengan } \\
\text { pemberatan } 3 \text { (tiga) kali. } \\
\text { c. Pidana tambahan berupa } \\
\text { pencabutan izin usaha; } \\
\text { ataupencabutan status } \\
\text { badan hukum. }\end{array}$ \\
\hline
\end{tabular}

Berdasarkan hasil penafsiran Bab Ketentuan Pidana di atas maka perbuatan yang termasuk dalam Tindak Pidana Penanggulangan Bencana (selanjutnya disebut TPPB) pada hakikatnya ada 3 (tiga), yaitu:

1. Perbuatan melakukan kegiatan pembangunan berisiko tinggi tanpa disertai analisis risiko bencana yang pada akhirnya menyebabkan terjadi bencana. Perbuatan ini diancam dengan pemberatan pidana apabila timbul kerugian harta benda atau barang atau korban jiwa. Pemberatan pidana juga diberikan apabila ada unsur kesengajaan.

2. Menghambat kemudahan akses BNPB dab BNPD, dalam hal: pengerahan sumber daya manusia; pengerahan peralatan; pengerahan logistik; imigrasi, cukai, dan karantina; perizinan; pengadaan barang/jasa; pengelolaan dan 
pertanggungjawaban uang dan/atau barang; penyelamatan; dan komando untuk memerintahkan sektor/lembaga.

3. Penyalahgunaan sumber daya bantuan bencana, baik dalam hal perencanaan, penggunaan, pemeliharaan, pemantauan, pengevaluasian terhadap barang, jasa, dan/atau uang bantuan nasional maupun internasional.

Ketiga perbuatan tersebut ditujukan kepada setiap orang, baik individu maupun korporasi. Oleh karena, dalam Pasal 1 angka ke-21 telah disebutkan bahwa: Setiap orang adalah orang perseorangan, kelompok orang dan/atau badan hukum. Dengan kata lain, pelaku dalam TPPB adalah orang perseorangan (individu), kelompok atau badan hukum (korporasi). Apalagi dalam Pasal 79 ayat (1) dan (2) telah dirumusakan mengenai ancaman pidana bagi suatu korporasi yang melakukan TPPB sebagaimana diatur dalam Pasal 75 sampai dengan Pasal 79.

\subsection{BEBERAPA ANALISIS ATAS BAB KETENTUAN PIDANA DALAM NO. 24}

\section{TAHUN 2007}

Setelah mengetahui perbuatan-perbuatan apa saja yang merupakan TPPB maka hal yang perlu dilakukan selanjutnya adalah menganalisis kebijakan formulasi yang terkait dengan penggunaan Bab Ketentuan Pidana dalam UUPB. Penggunaan Bab Ketentuan Pidana dalam UUPB berarti sama dengan penggunaan sanksi pidana dalam rangka menegakkan norma-norma yang telah dirumuskan dalam UU tersebut.

Penggunaan sanksi pidana dalam sebuah UU tertentu perlu memperhatikan adanya suatu sistem peraturan perundang-undangan di bidang hukum pidana yang bersifat saling terkait. Oleh karena, ketika suatu UU "berani" menggunakan sanksi pidana maka UU tersebut jelas akan menjadi salah satu sumber hukum pidana tertulis. Dalam kajian hukum pidana, yang merupakan sumber hukum pidana tertulis adalah KUHP dan UU Pidana Khusus di luar KUHP. Atau yang lebih dikenal dengan pembagian perundang-undangan pidana umum dan perundang-undangan pidana khusus.

Pembagian sumber hukum pidana tertulis tersebut janganlah didikhotomikan, oleh karena baik perundang-undangan pidana umum ataupun perundang-undangan pidana khusus saling terkait antara yang satu dengan yang lain. Hal ini ditegaskan oleh Moeljatno, sebagaimana dikutip oleh Romli Atmasasmita (1997:46), dengan menyatakan bahwa: 
"KUHP merupakan inti atau induk peraturan hukum pidana. Diluar KUHP terdapat aturan-aturan pidana tersendiri..., antara KUHP dengan peraturanperaturan di luarnya ada hubungan yang erat, yaitu seperti induk dengan anakanaknya, artinya sistem yang dipakai dalam KUHP berlaku pula bagi peraturanperaturan di luarnya, kecuali jika nyata-nyata ditentukan sebaliknya".

Bertolak dari apa yang dikemukakan oleh Muljatno, maka hal mendasar harus dipahami bahwa keseluruhan peraturan perundang-undangan (statutory rules) di bidang hukum pidana substantif itu terdiri atas "aturan umum" (general rules) dan "aturan khusus" (special rules). Keberadaan "aturan umum" dan "aturan khusus" sebagai bagian dari hukum pidana substantif tersebut adalah berpedoman pada "keistimewaan" dari Buku I KUHP yang memuat asas-asas umum yang berlaku untuk Buku II dan Buku III KUHP dan juga UU khusus (Pasal 103 KUHP). Barda Nawawi Arief (2002:5) mengilustrasikan secara jelas tentang kedudukan dari "aturan umum" dan "aturan khusus" dalam sistem hukum pidana substantif dalam gambar berikut ini:

Gambar 1: Sistem Hukum Pidana Substantif

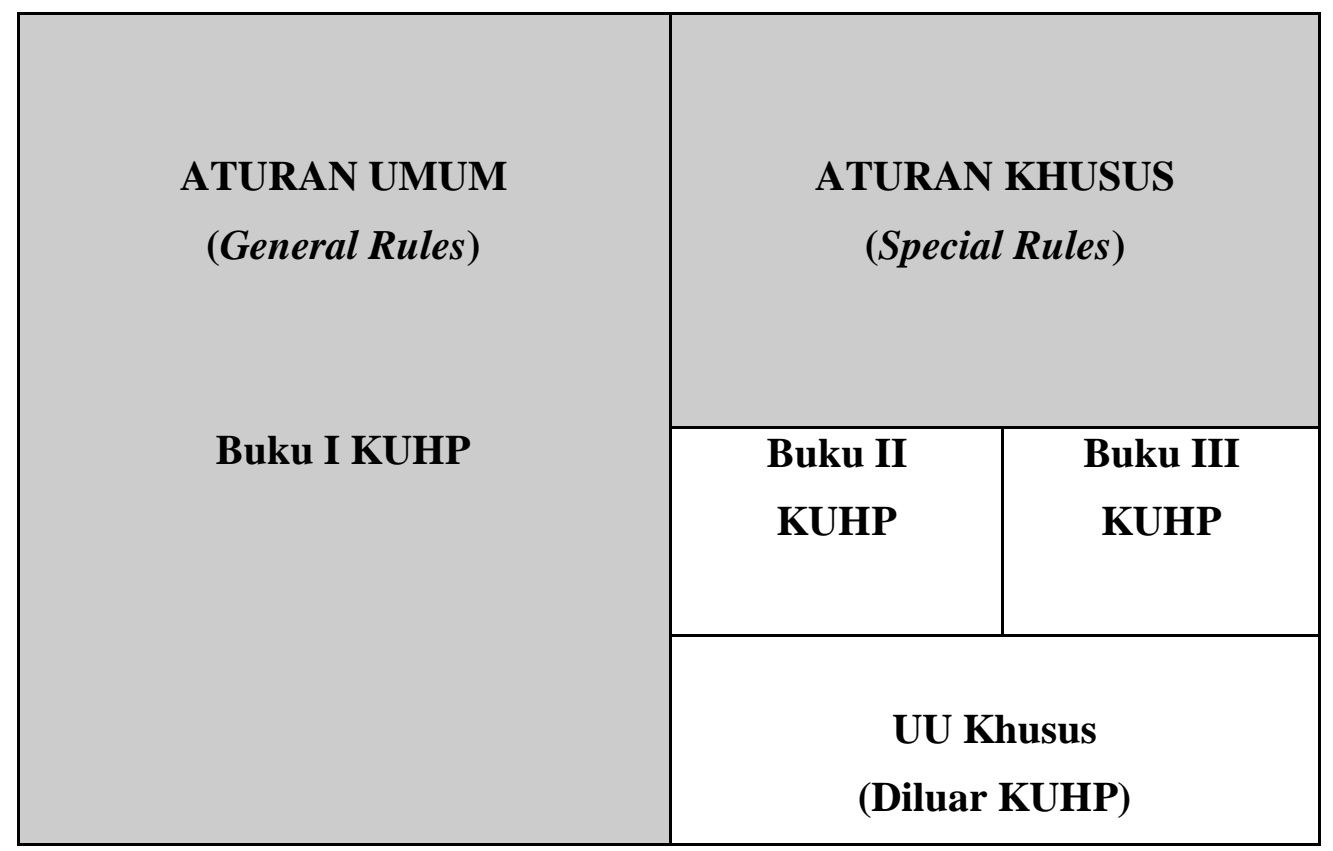

Gambar tersebut menegaskan bahwa "aturan umum" terdapat dalam Buku I KUHP. Aturan umum tersebut memuat asas-asas umum yang berlaku untuk Buku II dan Buku III, dan juga UU pidana khusus di luar KUHP. Oleh karena itu, UUPB sebagai UU pidana khusus di luar KUHP harus sinkron dengan "aturan umum” terdapat 
dalam Buku I KUHP. Berikut ini akan dikemukakan beberapa analisis Bab Ketentuan Pidana dalam UUPB dengan "aturan umum” yang terdapat dalam Buku I KUHP.

1. Masalah kualifikasi delik: "Kejahatan" atau "Pelanggaran".

Bagi masyarakat umum, seringkali istilah kejahatan; tindak pidana; pelanggaran; perbuatan pidana; perbuatan melanggar hukum; atau delik dipahami dengan pengertian yang sama, yaitu suatu perbuatan terlarang dan diancam pidana bagi yang melakukannya. Namun demikian, dari sisi ilmu hukum pidana, penggunaan istilah tersebut dapat memiliki konsekuensi yuridis yang berbeda. Penetapan suatu perbutan melanggara hukum sebagai "Kejahatan" akan memiliki beberapa konsekuensi yuridis yang berbeda dengan "Pelanggaran".

Bagaimana dengan UUPB? Ternyata UUPB tidak menyebutkan kualifikasi delik dalam TPPB. Tentu hal ini akan menimbulkan masalah yuridis. Permasalahnnya antara lain dalam hal terjadinya kasus "percobaan", "pembantuan", concursus", "daluwarsa penuntutan dan pelaksanaan pidana", "berlakunya asas nasional aktif dalam Pasal 5 ayat (1) ke-2 KUHP", dan sebagainya. Sehubungan dengan itu, Barda Nawawi Arief (2001:151) menegaskan bahwa penetapan kualifikasi delik sebagai kejahatan atau pelanggaran merupakan "penetapan kualifikasi yuridis" yang mempunyai akibat atau konsekuansi yuridis, baik dalam arti konsekuensi yuridis-materiel (yaitu terikat pada aturan umum KUHP) maupun kualifikasi yuridis-formal (dalam KUHAP), sepanjang tidak ditentukan lain oleh undang-undang. Penetapan kualifikasi yuridis ini diperlukan untuk 'menjembatani' berlakunya aturan umum KUHP terhadap hal-hal yang tidak di atur dalam undang-undang di luar KUHP.

Dengan demikian, seyogyanya dalam pasal terakhir pada Bab Ketentuan Pidana mengatur ketentuan tentang kualifikasi delik TPPB. Sebagaimana dalam beberapa UU pidaka khusus lainnya, seperti: UU 7/92 jo. UU 10/98 (Perbankan); UU 5/97 (Psikotropika); UU 23/97 (Pengelolaan Lingkungan Hidup); UU 32/97 (Perdagangan Berjangka Komoditi); dan UU 39/99 (Telekomonikasi). Artinya, ada penegasan kualifikasi delik. Masalahnya sekarang adalah: apakah TPPB yang telah diatur dalam Pasal 75 sampai dengan 79 UUPB akan dikualifikasikan sebagai "Kejahatan" atau "Pelanggaran"? Apabila melihat ancaman pidana penjara dan denda yang cukup tinggi sepertinya pembuat UUPB ingin menempatkan TPPB sebagai delik yang berkualifikasi kejahatan, bukan pelanggaran.

2. Masalah Perumusan Pelaku Korporasi 
Penetapan korporasi sebagai subjek tindak pidana atau subjek hukum pidana disamping manusia alamiah (natuurlijk persoon) dalam beberapa perundang-undangan pidana khusus, pada hakikatnya dapat dilakukan dan dibenarkan. Sebab, peranan korporasi yang semakin besar dalam berbagai bidang - khususnya bidang perekonomian - menimbulkan kecenderungan bagi korporasi untuk melakukan kejahatan dalam mencapai tujuannya.

Namun demikian, penentuan pelaku korporasi dalam UUPB masih perlu di evaluasi. Oleh karena dalam UUPB tersebut belum merumuskan secara rinci hal-hal yang terkait dengan pelaku korporasi. Minimal ada 2 (dua) hal yang harus diperhatikan dalam pembaharuan UUPB sehubungan dengan pelaku korporasi dalam TPPB.

Pertama, penentuan kapan suatu korporasi dinyatakan sebagai pelaku atau telah melakukan tindak pidana, dan kapan suatu tindak pidana telah dilakukan atas nama suatu korporasi. Hal ini harus dirumuskan secara tegas. Sebab, perumusan yang tidak tegas akan menimbulkan persoalan dalam aplikasinya. Kedua, kriteria-kriteria apa yang dapat digunakan sebagai pedoman untuk mempertanggungjawabkan korporasi. Sebab pertanggungjawaban dalam hukum pidana senantiasa dikaitkan dengan masalah kesalahan, yaitu menyangkut kemampuan bertanggungjawab, kesengajaan atau kealpaan dan unsur ketiadaaan alasan pemaaf.

\section{Masalah Perumusan Sanksi Untuk Korporasi}

Dalam ilmu hukum pidana dan kriminologi, korporasi dapat melakukan tindak pidana apa saja, tapi ada pembatasannya. Korporasi tidak bisa dikatakan melakukan tindak pidana dalam hal: (a) adanya perumusan ancaman pidana tunggal, berupa pidana yang hanya bisa dilakukan oleh orang biasa, misalnya delik-delik yang diancam pidana penjara secara tunggal; dan (b) tindak pidana yang hanya bisa dilakukan oleh orang biasa, misalnya bigami, perkosaaan atau zina, sumpah palsu, dan sebagainya. Mengenai hal ini, Peter Gillies, sebagaimana dikutip dan disarikan oleh Barda Nawawi Arief (2002a:150) menyatakan bahwa:

"Ada batas-batas delik mana yang dapat dilakukan oleh perusahaan (korporasi. Pen). Salah satu pertimbangan yang relevan adalah masalah pidana. Secara normal, pidana yang dapat dikenakan kepada perusahaan adalah pidana denda, oleh karena itu apabila suatu delik hanya diancam dengan pidana penjara tidaklah mungkin dikenakan kepada perusahaan (korporasi. Pen). Di Australia, perusahaan (korporasi. Pen) akan dinyatakan tidak mampu melakukan pembunuhan (murder), karena delik ini hanya diancam dengan pidana penjara". 
Berdasarkan uraian di atas, maka dapat disimpulkan bahwa pidana penjara dan pidana mati tidak dapat dijatuhkan kepada korporasi. Sanksi yang bisa dijatuhkan pada korporasi adalah: pidana denda; pidana tambahan; tindakan tata tertib; sanksi administrasi atau tindakan administratif; dan sanksi perdata atau ganti kerugian. Mengingat KUHP menganut sistem dua jalur (double track system) dalam pemidanaan, dalam arti di samping sanksi pidana dapat juga dikenakan sanksi tindakan kepada si pelaku, maka sistem ini dapat pula diterapkan dalam pertanggungjawaban korporasi sebagai pelaku tindak pidana. Sesuai dengan motif-motif kejahatan korporasi, sanksi yang bersifat ekonomis dan administratif tampaknya lebih sesuai diterapkan dalam pertanggungjawaban korporasi (Setiyono, 2002:152).

Dalam UUPB dirumuskan bahwa selain sanksi pidana denda, terhadap korporasi juga dapat dikenakan sanksi pidana tambahan berupa: pencabutan izin usaha atau pencabutan status badan hukum. Dalam rangka pembaharuan UUPB kiranya perlu diteliti lebih lanjut dalam rangka menginventarisasi bentuk-bentuk sanksi pidana tambahan atau bentuk-bentuk sankai tindakan yang dapat dikenakan pada korporasi yang terbukti melakukan TPPB. Dengan kata lain, perlu digali bentuk-bentuk sanksi yang variatif selain pencabutan izin usaha atau pencabutan status badan hukum.

4. Masalah Perumusan Ancaman Pidana Minimal Khusus

Perumusan ancaman pidana dalam UUPB menunjukkan bahwa UU tersebut menggunakan sistem minimal khusus. Artinya, adanya ancaman pidana minimal atas perbuatan tertentu. Misalnya, dalam Pasal 75 ayat (3) UUPB merumuskan bahwa: “....dipidana dengan pidana penjara paling singkat 8 (delapan) tahun atau paling lama 10 (sepuluh) tahun dan denda paling sedikit Rp. 3.000.000.000,00 (tiga miliar rupiah) atau denda paling banyak Rp. 6.000.000.000,00 (enam miliar rupiah).” Pola minimal khusus tampak dari perumusan kata "paling singkat" sebagaimana yang dicetak tebal di atas. Dalam KUHP tidak dikenal adanya pola demikian. Yang ada adalah pola minimal umum. Jadi, UUPB berkeinginan untuk mengatur menyimpang dari sistem yang ada dalam KUHP.

Kebijakan untuk menggunakan ancaman pidana minimal khusus dalam UUPB memang dapat dilakukan. Namun demikian, adanya ancaman pidana minimal khusus dalam UUPB tersebut seharusnya disertai dengan pedoman atau aturan penerapan pidana minimal yang bersifat khusus pula. Harus ada pedoman bagi hakim pada saat 
akan menerapkan aturan pidana minimal khusus tersebut. Terkait dengan itu, Barda Nawawi Arief (2001:201) menegaskan bahwa:

Tanpa pedoman atau aturan khusus, bisa menimbulkan masalah karena dalam aturan umum KUHP belum ada aturan pemidanaan untuk menerapkan ancaman pidana minimal. Tidak adanya aturan pemidanaan khusus untuk menerapkan sistem minimal itu mungkin tidak menjadi masalah untuk pelaku (pleger) yang melakukan delik selesai (voltooid delicten). Namun dapat menjadi masalah apabila ada masalah penyertaan, percobaan, concursus, recidive, dan lain-lain alasan peringanan atau pemberatan pidana (Kursif. Pen). Dalam kenyataan praktek, hakim mengalami kesulitan menerapkan ancaman pidana minimal ini; sehingga ada hakim yang menjatuhkan pidana di bawah ancaman minimal (kursif. Pen).

Pada kesempatan lain, Barda Nawawi Arief (2003:23) menyatakan secara lebih tegas dan tajam, bahwa:

"apabila dilihat dari sistem pemidanaan, jumlah ancaman pidana (minimum maupun maksimum) hanya merupakan salah satu sub-sistem (garis bawah. Pen) yang tidak dapat begitu saja diterapkan atau dioperasionalisasikan hanya dengan diancamkan di dalam perumusan delik. Agar dapat diterapkan, harus disertai dengan sub-sistem mengenai aturan pemidanaan atau pedoman pemidanaanya terlebih dahulu (garis bawah. Pen)".

Sehubungan dengan itu, maka dapat disimpulkan bahwa penggunaan sistem atau pola minimal khusus dalam UUPB dapat dibenarkan. Namun demikian, digunakannya sistem atau pola minimal khusus harus diikuti juga dengan perumusan pedoman atau aturan pemidanaan yang khusus pula. Dengan demikian, ancaman pidana minimal khusus tersebut dapat dioperasionalisasikan dalam tahap aplikasi dan eksekusi.

\section{KESIMPULAN}

Berdasarkan uraian dan pembahasan yang telah dikemukakan, maka atas permasalahan yang dikemukakan dapat ditarik kesimpulan sebagai berikut:

1. Perbutan-perbuatan yang merupakan tindak pidana (dikriminalisasikan) dalam UUPB adalah:

a. Perbuatan melakukan kegiatan pembangunan berisiko tinggi tanpa disertai analisis risiko bencana yang pada akhirnya menyebabkan terjadi bencana. Perbuatan ini diancam dengan pemberatan pidana apabila timbul kerugian harta benda atau barang atau korban jiwa. Pemberatan pidana juga diberikan apabila ada unsur kesengajaan.

b. Menghambat kemudahan akses BNPB dab BNPD, dalam hal: pengerahan sumber daya manusia; pengerahan peralatan; pengerahan logistik; imigrasi, 
cukai, dan karantina; perizinan; pengadaan barang/jasa; pengelolaan dan pertanggungjawaban uang dan/atau barang; penyelamatan; dan komando untuk memerintahkan sektor/lembaga.

c. Penyalahgunaan sumber daya bantuan bencana, baik dalam hal perencanaan, penggunaan, pemeliharaan, pemantauan, pengevaluasian terhadap barang, jasa, dan/atau uang bantuan nasional maupun internasional.

2. Beberapa hal yang perlu diperhatikan dalam rangka pembaharuan bab ketentuan pidana UUPB di masa mendatang adalah: Pertama, perlu penegasan dalam perumusan kualifikasi delik, berupa "kejahatan" ataukah "pelanggaran". Kedua, perlu pengkajian ulang atau pembaharuan (re-formulasi) tentang pelaku TPPB, terutama untuk pelaku kelompok orang orang dan badan hukum (korporasi). Ketiga, perlu pengkajian ulang tentang perumusan ancaman pidana terhadap pelaku korporasi, terutama dengan menggali sanksi-sanksi yang lebih relevan dengan karakteristik pelaku korporasi dalam hal kebencanaan. Keempat, mengingat UUPB menentukan ancaman pidana minimal khusus maka perlu adanya pedoman pemidanaan dalam menerapkan aturan tersebut. Tanpa adanya pedoman pemidanaan maka pemidanaan yang diberikan oleh hakim dapat saja kembali ke aturan umum dalam KUHP yang hanya mengenal ancaman pidana minimal umum.

\section{SARAN}

Adapun saran yang dapat diberikan adalah:

1. Selain menyiapkan substansi hukum (peraturan perundang-undangan) dan struktur hukum (kelembagaan), seyogyanya dilakukan upaya-upaya strategis dalam menyiapkan kultur hukum (budaya masyarakat) dalam menghadapi persoalan kebencanaan atatu penanggulangan bencana dalam. Jadi, ada sinergi antara substansi hukum, struktur hukum dan kultur hukum. Sehubungan dengan itu, maka perlu dibangun "Budaya Sadar Bencana" di masyarakat.

2. Perlu dilakukan pengkajian lebih lanjut atas berbagai peraturan perundangundangan yang memiliki keterkaitan dengan UUPB agar terjadi sinkronisasi atau harmonisasi hukum. Harus ada aturan yang sinergis, mulai dari UU, PP, Keppres, Perda, termasuk peraturan menteri ataupun peraturan kepala BNPB dalam mengantisipasi masalah kebencanaan. 


\section{DAFTAR PUSTAKA}

Buku dan Jurnal

Andi Hamzah, Perkembangan Hukum Pidana Khusus, Rineka Cipta, Jakarta, 1994.

Bapennas dan UNDP, Laporan Akhir Inisiatif Harmonisasi Hukum Untuk Desentralisasi Perencanaan Pembangunan Dalam penanggulangan Bencana, Bapennas, Jakarta, 2008.

Barda Nawawi Arief, Masalah Penegakan Hukum dan Kebijakan Penanggulangan Kejahatan, Citra Aditya Bakti, Bandung, 2001.

Barda Nawawi Arief, Pengaturan Cyber Crime Dalam Hukum Pidana (Beberapa Catatan Terhadap Ketentuan Pidana dalam RUU Teknologi Informasi), Makalah Pada Seminar Nasional Cyber Law, BEM Fakultas Hukum UNDIP, Semarang, 13 April 2002.

Barda Nawawi Arief, Sari Kuliah Perbandingan Hukum Pidana, Rajawali Grafindo Persada, Jakarta, 2002 (a).

Barda Nawawi Arief, Tindak Pidana Pencucian Uang dan Tindak Pidana Lainnya Yang Terkait, dalam Jurnal Hukum Bisnis Vol. 22-No.3-2003, Menyongsong Amandemen UU 15/2002, Yayasan Pengembangan Hukum Bisnis, Jakarta, 2003.

Loebby Loqman, Kapita Selekta Tindak Pidana di Bidang Perekonomian, Datacom, Jakarta, 2002.

Muladi, HAM, Politik, dan Sistem Peradilan Pidana, BP UNDIP, Semarang, 1997. Romli Atmasasmita, Tindak Pidana Narkotika Dalam Sistem Hukum Pidana Indonesia, Citra Aditya Bakti, Bandung, 1997.

Setiyono, Kejahatan Korporasi, Averroes Press, FH UNMER dan Pustaka Pelajar, Malang, 2002.

Soedarto, Hukum Dan Hukum Pidana, Alumni, Bandung, 1986.

Peraturan Perundang-undangan

Undang-Undang No. 24 Tahun 2007 tentang Penanggulangan Bencana

\section{Media Massa}

Kompas, 2,2 Juta Penduduk Tewas karena Bencana, 19 Mei 2009 